Article

\title{
Diverse Scale Data for Shale Gas Formation Description-Why Is Digital Shale Rock Model Construction Difficult? The Polish Silurian and Ordovician Rocks Case Study
}

\author{
Paulina I. Krakowska-Madejska *(i) and Jadwiga A. Jarzyna \\ Department of Geophysics, Faculty of Geology Geophysics and Environmental Protection, AGH University of \\ Science and Technology, 30-059 Krakow, Poland; jarzyna@agh.edu.pl \\ * Correspondence: krakow@agh.edu.pl
}

Received: 25 November 2019; Accepted: 24 January 2020; Published: 27 January 2020

check for updates

\begin{abstract}
The aim of the study was to show that the petrophysical parameters, characterizing the shale gas formation, obtained from the various scale well logging and laboratory methods, correlated among themselves. Relationships determined on the basis of mesoscale (logs) and microscale outcomes (laboratory experiments on plugs or crumbs) were also recognizable in nanoscale in the computed tomography results. Selected logs (spectral gamma ray, resistivity, density, neutron, geochemical and acoustic logs) and laboratory methods turned out to be effective in rock typing and description of petrophysical parameters. Nanoscale results processing and interpretation was supported by the sophisticated special software poROSE (version 3.18, AGH University of Science and Technology, Kraków, Poland) to determine special parameters, which correlated with the standard laboratory outcomes. Results of the mercury injection porosimetry, together with adsorption/desorption of nitrogen at $77 \mathrm{~K}$ and pressure decay permeability, were used as the basal parameters for building a digital model of shale rock and a detailed description of the Silurian and Ordovician shale formation, treated as the hydrocarbon prospective unconventional reservoirs. Including the computed X-ray tomography results in the correlation analyses, gave the platform to extend the standard 2D approach in building the rock model to novel, 3D and more detailed presentations of rock characteristics.
\end{abstract}

Keywords: shale formations; spectral gamma ray log; electric imaging log; mercury injection porosimetry; gas adsorption/desorption; computed X-ray tomography

\section{Introduction}

The broad discussion on shale gas as a potential source of hydrocarbon production took place in Poland in the first two first decades of the twenty-first century. Many industrial and scientific units were engaged in prospection, completion and exploitation works in order to provide information on the industrial production from the Polish shale gas formations [1,2]. Shale gas deposits belong to unconventional hydrocarbon resources. The most important issue regarding these type of deposits, is porosity volume and pore space structure determination, which allow the understanding of the quantity and location of shale gas resources. Nowadays, unconventional resources in Poland, mostly tight gas and shale gas, are under careful and detailed considerations regarding cognitive works. There is worldwide interest in prospection of unconventional deposits, because of the necessity to increase energy production and consciousness of geological limitations regarding conventional hydrocarbon deposits.

The multidimensional analysis of the available data of diverse scale is presented in the paper. The results from the well logging and laboratory experiments were included, especially designed for 
shale gas formation recognition. The research purpose is to show how the various scale measurements provide indispensable information and also to show how the data mutually complete the knowledge on this very complicated geological formation. Results of the standard applied geophysical methods (seismic and well logging) were used in introduction of the specific applications. They represent macroscale and mesoscale research and data, which were considered at the very beginning of the analysis to define the potential shale gas deposits. Laboratory results were the source of the microscale data. New technologies, such as computed X-ray tomography, represent additional, very useful information on the microstructure of shale gas rocks in microscale or nanoscale. Correlations of various laboratory outcomes with well logging data, i.e., logs and results of the quantitative interpretation, were considered as an effective tool for a shale gas model construction, among other solutions.

The complex relationship between porosity and permeability made estimations of flow behavior complicated, due to heterogeneous pore networks in shale gas. Even though permeability slightly increased with porosity, permeability of samples with similar porosity differed by up to three orders of magnitude, starting with very low values. Thus, the absolute permeability prediction yielded large uncertainty. The complicated structure of the pore space in shales and the gas presence, not only in pores but also in matrix, as well as the existence of different mechanisms of gas flow, gave the assumption to use many available methods and combine the results. The relationships between connected versus unconnected pores were especially of prime importance for quantitative reservoir models.

Examples discussed in this paper originated from known and broadly tested potential Silurian and Ordovician shale gas formations from the Baltic Basin, because a large data set was gathered and accessible during the numerous industry prospection works and scientific projects [3-7]. Attention was focused on the combination between laboratory results, obtained on standard size samples and using the information from computed X-ray tomography (CT) as a tool for the description of shale gas model in more detailed way.

\section{Geological Setting and Materials}

Petrophysical analyses were based on the results of laboratory measurements and well logging data. Samples from the selected depth intervals of the lithostratigraphic profiles and well logging data from the same sections in three wells (Well-1, Well-2 and Well-3) were considered. Wells are sited in the Peri-Baltic Syneclise (Figure 1), north of Poland. Detailed geological description, combined with well logging information and geochemical TOC data, were considered in primary analyses. Jantar Member (Ja Mb) of the Silurian Pasłęk Formation (Pa Fm) and Ordovician Sasino Formation (Sa Fm), as potential resources of unconventional hydrocarbons, were selected for the analyses (Table 1).

Table 1. Stratigraphy in Well-1, Well-2 and Well-3 (partial information in the depth section between Pa Fm and Ko Fm).

\begin{tabular}{cccc}
\hline Stratigraphy & \multicolumn{3}{c}{ Depth Interval (m) } \\
\hline $\begin{array}{c}\text { Silurian, Llandovery Pasłęk Formation } \\
\text { (Pa Fm) }\end{array}$ & Well-1 & Well-2 & Well-3 \\
\hline $\begin{array}{c}\text { Silurian, Llandovery Jantar Member } \\
\text { (Ja Mb) in Pa Fm }\end{array}$ & $3198.1-3212.0$ & $2895.00-2906.90$ & $2871.1-2884.0$ \\
\hline $\begin{array}{c}\text { Ordovician, Ashgillian Prabuty } \\
\text { Formation (Pr Fm) }\end{array}$ & $3212.0-3217.5$ & $2907.00-2914.90$ & $2884.1-2892.0$ \\
\hline $\begin{array}{c}\text { Ordovician, Caradocian, Llanvirnian } \\
\text { Sasino Formation (Sa Fm) }\end{array}$ & $3217.6-3237.0$ & $2915.00-2940.90$ & $2892.1-2917.5$ \\
\hline $\begin{array}{c}\text { Ordovician, Llanvirnian, Llandeilian } \\
\text { Kopalino Formation (Ko Fm) }\end{array}$ & $3237.1-3249.0$ & $2941.00-2958.00$ & $2917.6-2935.5$ \\
\hline
\end{tabular}


Silurian and Ordovician shales in Poland spread along the western margin of the East European Platform in Lublin, Podlasie and Baltic basins, extending about $700 \mathrm{~km}$ in length [8]. On Łeba Elevation, where the wells are located, the sedimentation of the organic-rich black shales with graptolites started in the Late Llanvirnian, reaching Wenlock [9]. Silurian Pa Fm was firstly described by [10]. An average thickness of the formation is 20-40 m, increasing from east to west and not exceeding $70 \mathrm{~m} \mathrm{[11].} \mathrm{Ja} \mathrm{Mb}$ is built of black bituminous claystones and belongs to the lower part of the Pa Fm. It is characterized by high oil-prone organic matter content, but the thickness of this bed does not exceed $12 \mathrm{~m}$. Ja Mb commonly contains pyrite. Ordovician Sa Fm was fully described by Modliński and Szymański in the works published in 1997 and 2008 [12,13]. Lithology of this formation is mainly comprised of black, dark grey and grey-greenish bituminous shales. The thickness of the Sa Fm increases from east to west and north-west, from 3.5 to $37 \mathrm{~m}$ in the land part of the Baltic basin.

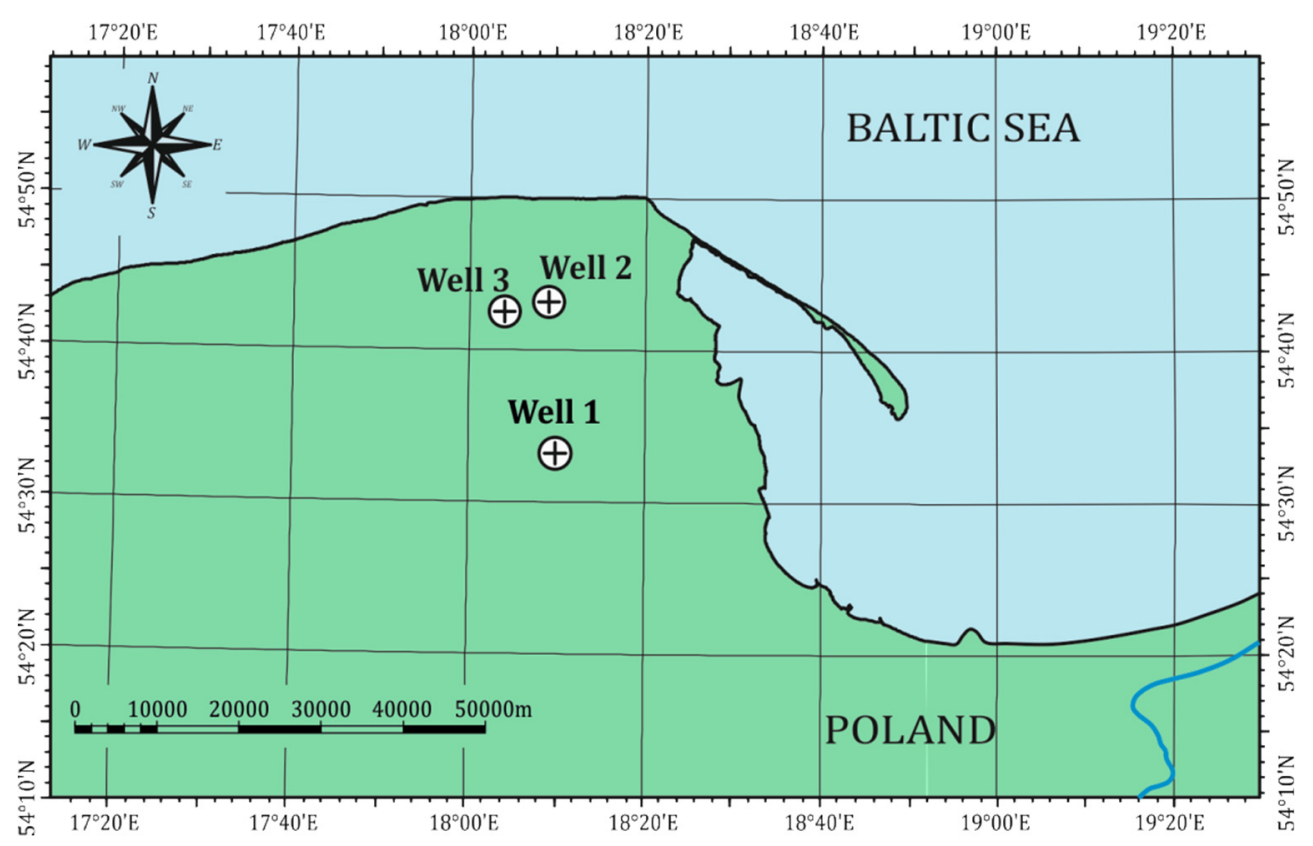

Figure 1. Locations of Well-1, Well-2 and Well-3 in the study area, north Poland, Peri-Baltic Syneclise.

\section{Methods}

Well logging is a basic method conducted in the well, in order to measure the physical and chemical parameters of the rocks in situ. The measuring set can consist of various logs. Thus, the information from the well logs can cover different parameters and be the input in calculation of reservoir parameters, such as porosity and permeability. The following well logs, which are based on the different physical or chemical laws, were taken into consideration in the analysis: spectral gamma ray (uranium, thorium and potassium), resistivity logs from dual laterolog and from X-tended Micro Imager (XRMI), bulk density, volumetric photoelectric absorption index, $\mathrm{P}$ wave slowness, neutron porosity, geochemical $\log$ (GEM: dry elemental weight percent of selected elements and the volumetric percent of major and minor minerals). The results of the well logs interpretation were also considered: volume of fluids, i.e., free water, gas, clay water and kerogen, saturation (total water saturation, effective water saturation) and porosity (total and effective).

The following laboratory measurement results were considered in the analysis: mercury injection porosimetry (MIP), nuclear magnetic resonance spectroscopy (NMR), pulse/pressure decay permeability (PPP), absorption/desorption of nitrogen at $77 \mathrm{~K}$ and $\mathrm{X}$-ray diffraction (XRD). The computed X-ray microtomography $(\mathrm{CT})$ results are presented in the last step.

Mercury injection porosimetry (MIP) is a technique which determines petrophysical parameters, such as porosity and pore-throat size distribution, total pore area and bulk density through measuring 
the intruded mercury volume under increasing pressures [14,15]. Mercury intrusion into large macropores is realized with only slight pressure, whereas greater pressure is required to force mercury into small pores. The advantage of MIP is based on the large resolution, $400 \mu \mathrm{m}$, down to $3 \mathrm{~nm}$. Nevertheless, this method cannot provide any information about isolated pores. MIP experiments were done at the AGH University of Science and Technology (AGH UST), Faculty of Geology, Geophysics and Environmental Protection (FGGEP) using AutoPore IV 9500 (Micromeritics Instrument Corporation). The next described method, a gas sorption, is a complementary technique to the mercury injection porosimetry.

The physical adsorption of nitrogen at $77 \mathrm{~K}$ method can reduce the smallest size measurement to about $0.00035 \mathrm{~mm}$ in diameter by investigating the intraparticle microstructure. Nitrogen adsorption/desorption isotherms, obtained with an automatic gas adsorption equipment (Quantachrome Autosorb-1C automatic gas adsorption apparatus), were used to characterize the porous texture, i.e., the pore size distribution and specific surface area of extremely low pore diameters. The Brunauer-Emmet-Teller (BET), Barrett-Joyner-Halenda (BJH) and quenched solid density functional theory (QSDFT) approaches are usually used for the interpretation of nitrogen adsorption data [16-19]. For shales, with the observed mesoporosity, the nitrogen adsorption isotherms are Type IV (isotherms with hysteresis loop), according to the International Union of Pure and Applied Chemistry (IUPAC) classification [20-22]. The samples were degassed overnight, under vacuum at $473 \mathrm{~K}$, before the physical adsorption of nitrogen measurements and other experiments. Measurements were made at the AGH UST, Faculty of Energy and Fuels (FEF).

NMR relaxometry for hydrogen nuclei was realized also at the AGH UST, FGGEP using Maran Ultra $23 \mathrm{MHz}$ spectrometer [23,24]. NMR signals, from water saturated plugs, carried information about water content and pore space volume, especially total and effective (dynamic) porosity and irreducible water saturation parameter.

Pressure decay permeability was measured on crushed grains of shale. Crushing of shales allowed for access of working fluid to the pore space. Bulk density was determined on the same plugs. Measurements were done by Terra Tek-Schlumberger Reservoir Laboratory [3].

Pulse decay permeability method was also applied for selected plugs. It was extremely difficult to plug shales. Samples, in the plug form, contained no natural microfractures from the coring and processing stage of the core analysis, which enhance or artificially increase permeability values and sometimes porosity values [25]. Permeability from pulse decay method confirmed high values of this parameter in several samples. Experiment was done at the AGH UST, Faculty of Drilling Oil and Gas. The minimum and maximum values of the parameter were interpreted considering two permeability values from pressure decay and pulse decay methods, respectively.

The computed X-ray microtomography images were acquired at the AGH UST, Faculty of Physics and Applied Computer Sciences by Nanotom S (General Electric) [26]. Resolution of the images was on the level of $0.6 \times 0.6 \times 0.6 \mu \mathrm{m}^{3}$ (volume of 1 voxel). Segmentation was done by threshold method, using a single threshold value determined by the choice of the interpreter, comparing the results of total porosity from CT with the results from the other laboratory techniques, such as FIB-SEM (Focused Ion Beam-Scanning Electron Microscope), helium pycnometry (HeP). Interpretation of the CT images was done using poROSE (poROus materials examination SoftwarE) computer system, developed at the AGH UST, FGGEP, Department of Geophysics [27-29].

A prototype set for water/light kerosene immersion porosimetry (dual liquid porosimetry) [30,31] was included. TOC and other parameters from the Rock-Eval pyrolysis were also considered.

XRD analyses were done in the Institute of Geological Sciences of Polish Academy of Sciences (ING PAS), Research Centre in Krakow. Measurements were carried out according to the methodology described in detail by Środoń et al [32], while interpretation used Q-Min software (Institute of Geological Sciences of Polish Academy of Sciences, Kraków, Poland) by Marek Szczerba (IGS PAS). Measured diffraction patterns were compared to the sum of pure standards, recorded for the identified minerals. Measured and synthetic diffraction patterns were compared until the difference was minimal [33]. Mineral content (normalized to 100\%) included organic matter (OM), calculated on the basis of total 
organic carbon content (TOC) from the Eltra CS-500 IR analyzer, as a difference between total carbon content (TC) and total inorganic carbon content (TIC) [3].

The assortment of laboratory measurements was very broad. All mentioned experiments were not able to be done on all samples, because of limited available rock material. The number of samples was limited, as regards the pressure decay permeability determination (together with bulk density) and microtomography analyses. Mercury injection porosimetry (MIP) was the basal method and its outcomes were available for all rock samples in the study and form the main group of the analyzed quantities. MIP outcomes were completed with results of the physical adsorption/desorption of nitrogen at $77 \mathrm{~K}$ measured in an automatic gas adsorption apparatus to extend the range of the examined pore radii. Four samples were used for the computed X-ray microtomography experiments. $\mathrm{CT}$ images as well as various TOC and mineral composition measures represented both Ja Mb and $\mathrm{Sa}$ Fm from two wells: Well-2 (three samples) and Well-1 (one sample).

The laboratory measurements listed above were done on the samples in the form of standard laboratory cylinders: 1 inch in diameter and more than 1 inch in height (e.g., pulse decay permeability), on the pieces (e.g., MIP, NMR, pressure decay permeability) or powders (e.g., XRD, HeP, absorption/desorption). Microtomographic investigations were done on very small parts of rock samples, approximately $0.5 \mathrm{~cm}$ in length. The idea was to carry out the measurements on the same part of material and on the homogeneous powder (pieces). MIP porosimetry is the destructive measurement, so it was done at the end of the measurement trial. Integrated well logging and laboratory analyses workflow is presented in the Figure 2, used to improve the rock typing and pore network characterization.

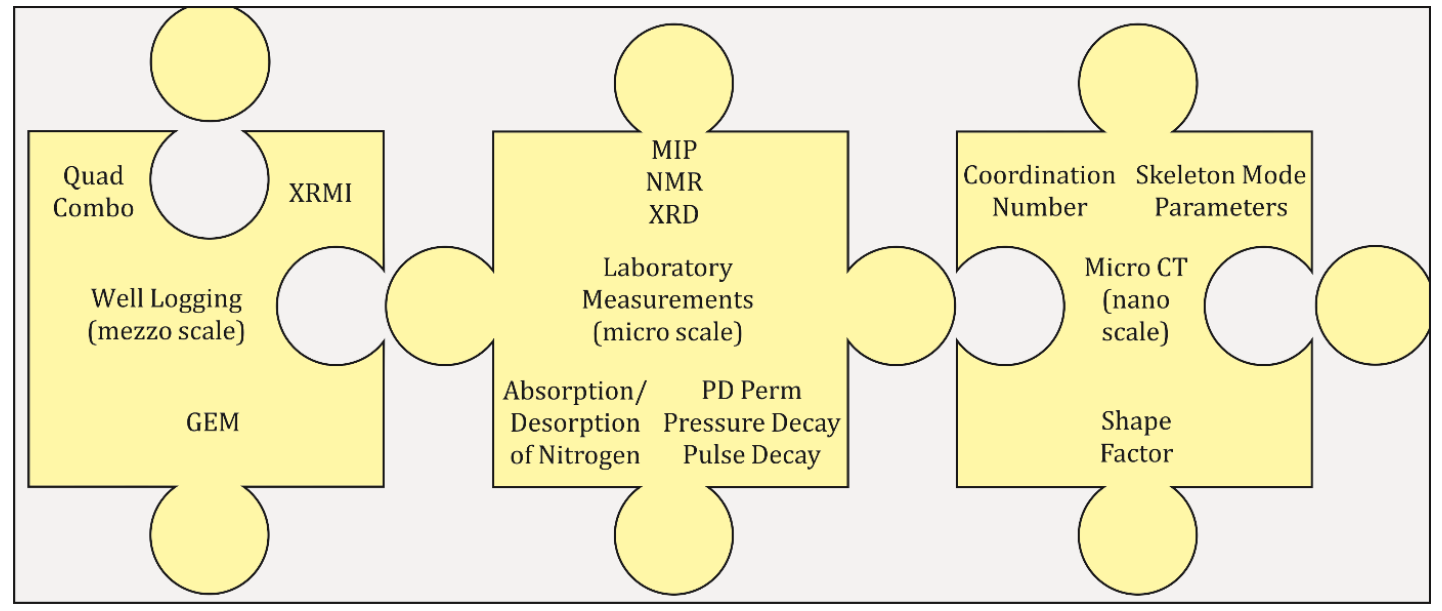

Figure 2. Integrated well logging and laboratory analyses workflow elaborated to improve the rock typing and pore network characterization.

\section{Results}

Well logs provided continuous data along well axis, but the standard logs available in well logging data set (Quad Combo) [34] turned out to be deficient in the vertical resolution (Figure 3) in the shale formation analysis. Nevertheless, the known and effective relationship between total organic carbon (TOC) from the laboratory measurements (for instance Rock-Eval analyses [35]) and uranium content (from the spectral gamma ray log) were successfully included, giving the basic information on parts of shales in the total geological profile that were rich in organic matter (and potentially in natural gas) (Figure 4). Electric borehole images, provided by the modern tools, such as FMI and XRMI [36,37], are a source of detailed lithology plots, illustrating changes of thickness of claystone and mudstone laminas in gas shales. These images, compared with photos of cores, were included to present the structure of the formation (Figure 3). Moreover, the results of the geochemical log (GEM or Litho Scanner) enriched well logging data with precise information of elemental structure of rocks, helping in differentiation between various elements, especially organic and nonorganic carbon (Figure 5). 


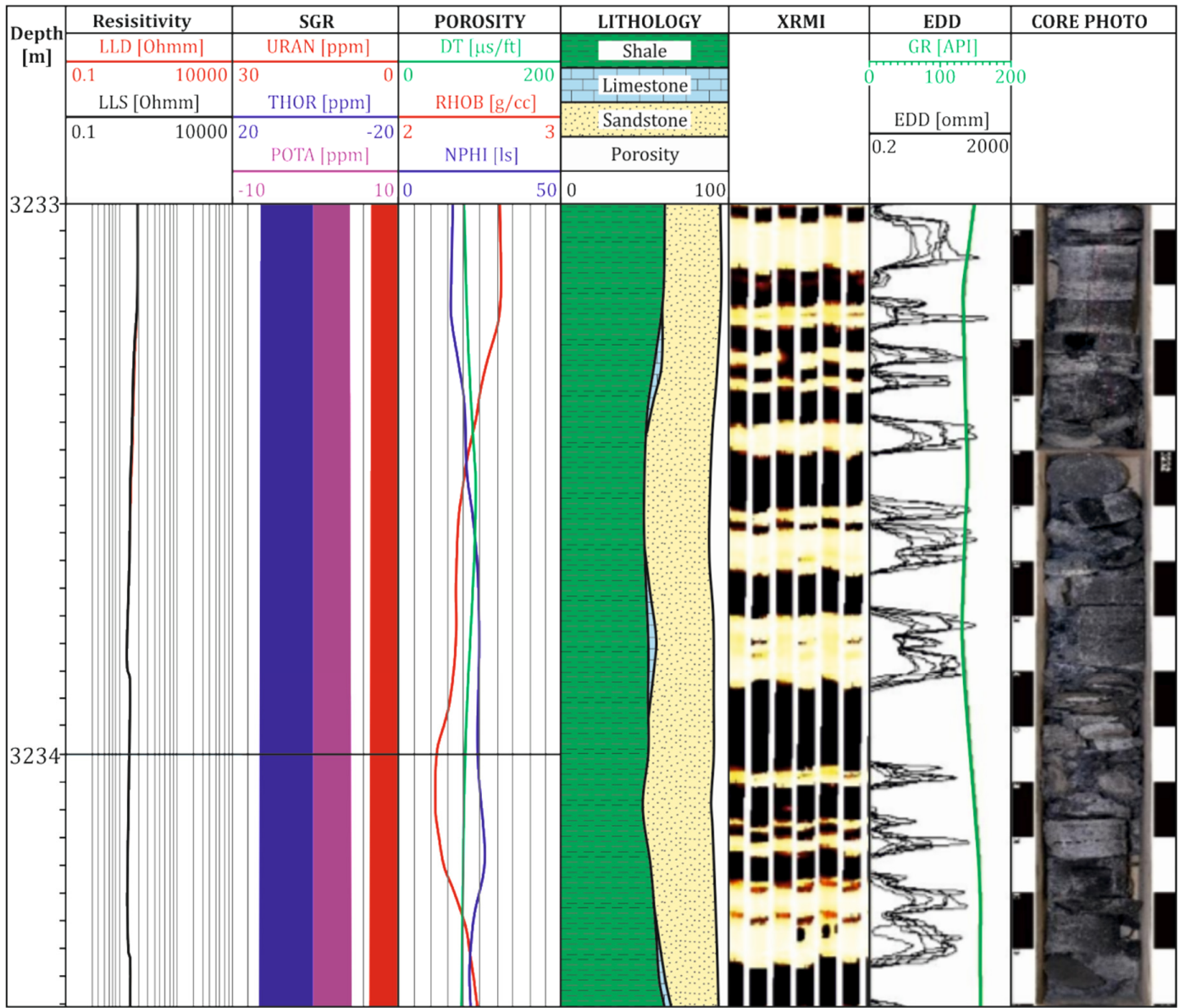

Figure 3. Results of the standard well logging data: electrical resistivity LLD (deep) and LLS (shallow) on track 1; spectral gamma ray logs SGR on track 2; sonic, density, neutron logs on track 3 (porosity $\operatorname{logs}$ ); lithology, as a result of the comprehensive interpretation of standard logs on track 4; electric image of the borehole wall on track 5; selected microresistivity curves EDD from the XRMI (X-tended Range Micro Imager) and GR (gamma ray log) on track 6; photos of the cores on track 7; Well-1, depth interval 3233-3234.45 m.

Figure 5 presents the selected standard logs in the typical way. The following logs are plotted versus depth: in the first track there is depth; in the second-spectral gamma ray SGR curves, i.e., uranium URAN (ppm), thorium THOR (ppm) and potassium POTA (\%); in the third, electrical resistivity logs from dual laterolog (LLD and LLS (ohm)); in the fourth track-bulk density RHOB $(\mathrm{g} / \mathrm{cc})$, volumetric photoelectric absorption index PE (barn/electron) and density of matrix RHOMA $(\mathrm{g} / \mathrm{cc})$, P wave slowness DT $(\mu \mathrm{s} / \mathrm{ft})$ and neutron porosity NPHI (ls, limestone porosity units). Results of geochemical log GEM are visualized as dry elemental weight percent of $\mathrm{Mg}, \mathrm{Al}, \mathrm{Si}, \mathrm{S}, \mathrm{K}, \mathrm{Ca}(\mathrm{wt} \%)$ in the fifth track. Results of the volumetric percent of major and minor minerals: illite, Fe chlorite, plagioclase, quartz, dolomite, calcite and kerogen are included in the sixth track. Next, volume of fluids, i.e., free water, gas, clay water and kerogen (\%) are shown in seventh track. Saturation: total water saturation (SWT), effective water saturation (SWE (dec)) and porosity (Por) tot (total) and Por eff (effective) (dec) are presented in the eighth and ninth tracks, according to Halliburton GEM Mineralogical \& Petrophysical Well Log Analysis \& Interpretation (2013) [38]. It can be observed that the mostly dolomitic limestone is in the lower part of the Ordovician formation in Figure 5. The upper part is mostly interbedded siltstone, claystone, shale and marl. The core XRD data showed that the primary minerals building up the Ordovician and Silurian strata were illite, quartz, calcite, dolomite and plagioclase. Minor amounts of Fe chlorite and pyrite were also identified. Some minerals identified in other depth sections of the geological profile were not taken in consideration in this 
analysis. The core geochemical TOC data from the offset well was used to improve the kerogen volume estimation in the GEM interpretation.

Standard log curves are compared with the borehole wall resistivity image (sixth track) and selected microresistivity curves EDD from the XRMI and GR (seventh track), as well as the photos of the cores, in Figure 3. Typical, very thin-bedded shale formation is distinctly visible. Additionally, several to over a dozen centimeters thick laminas are clearly visible. EDD curves in comparison with GR and other standard logs show that the vertical resolution of the XRMI electric image is much better. In the first two parts of the Figure 3 it can be observed that standard logs, although providing continuous curves, are not precise enough. The depth plots of uranium content in comparison with point TOC laboratory data (Figure 4) showed the usefulness of spectral gamma log SGR for quick identification of shale formations sections rich in organic matter. In the next steps, the analysis was focused only to the potentially productive beds. Layers rich in the organic matter (kerogen) were also indicated in the comprehensive interpretation of well logs (Figure 3).

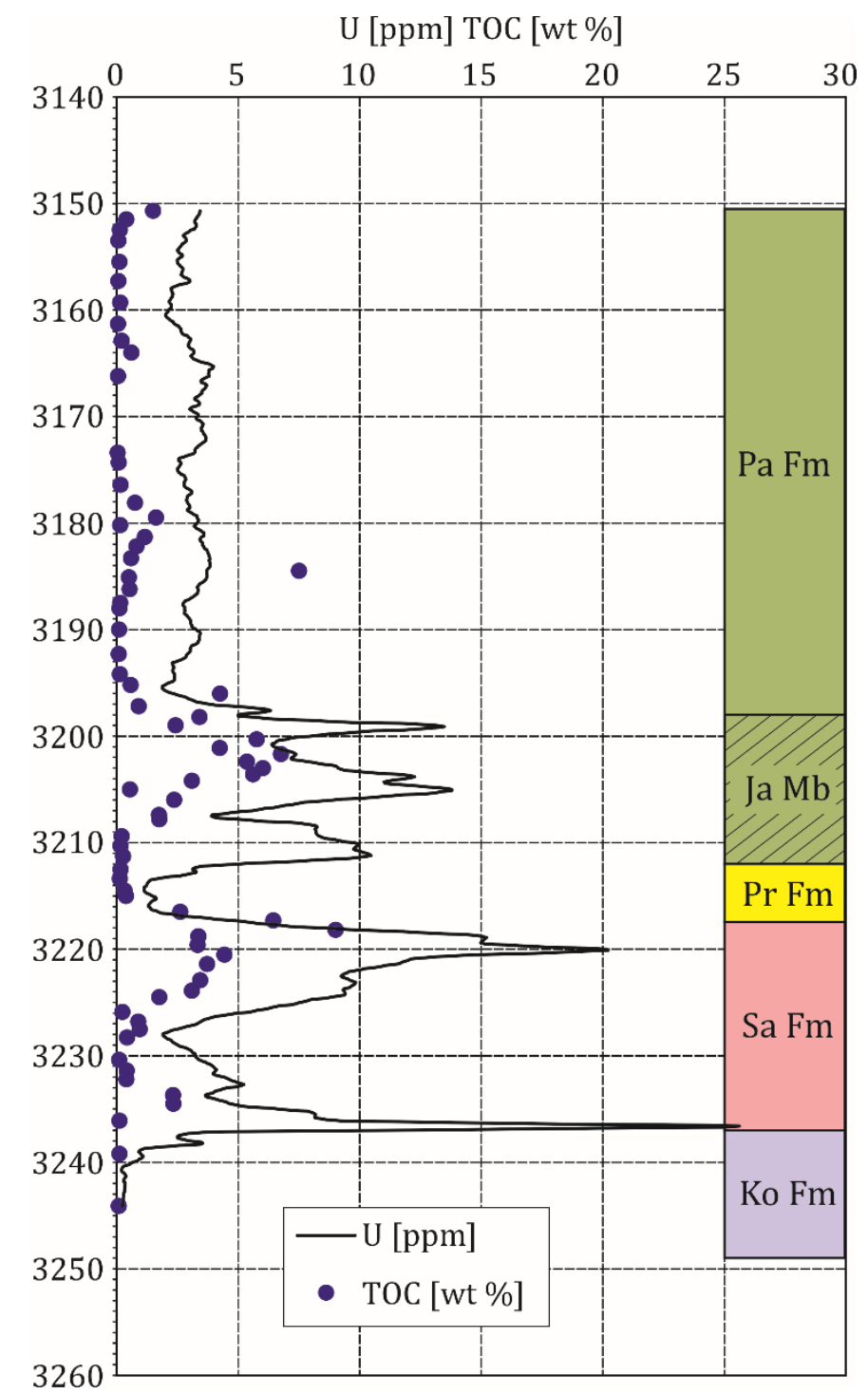

Figure 4. Uranium content (ppm) and TOC content (wt \%) vs. depth; Well-1, selected depth section. 


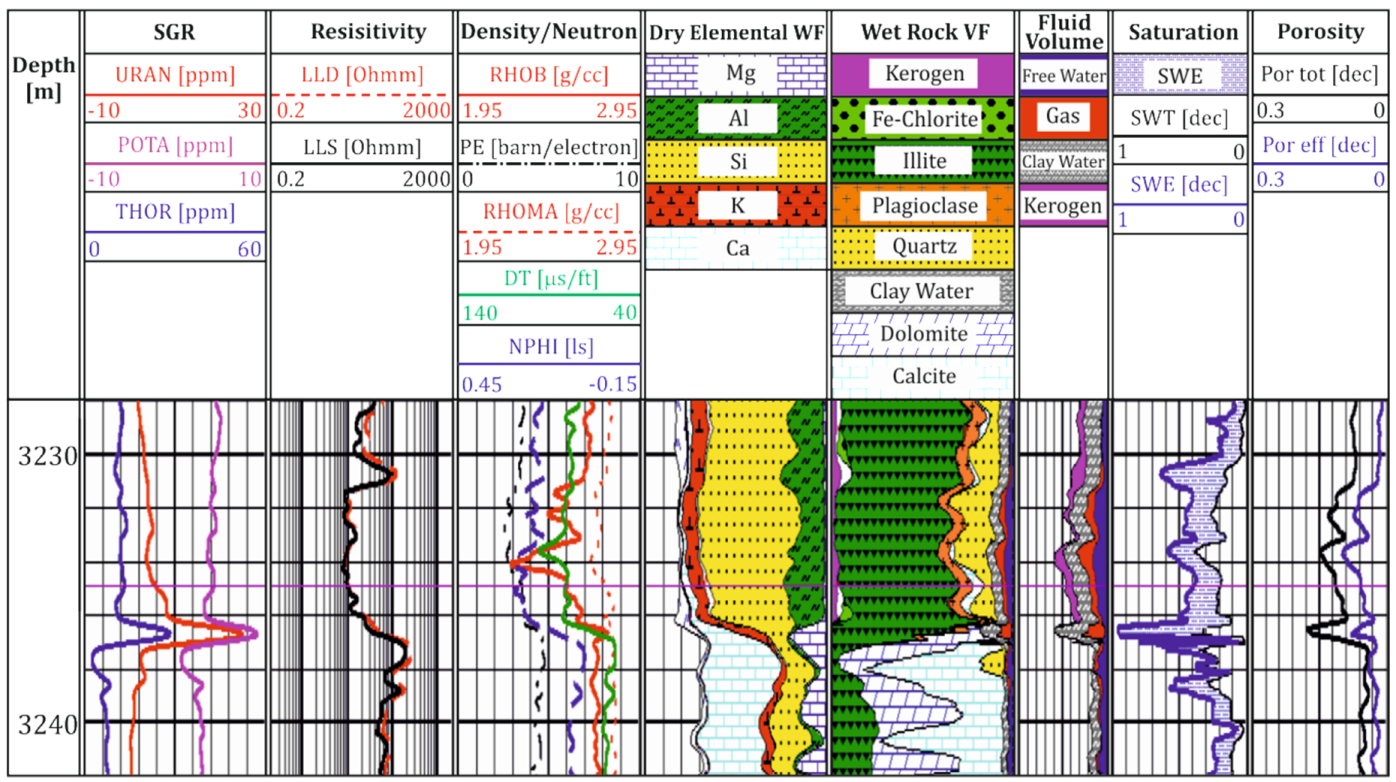

Figure 5. Results of the standard well logging (SGR, resistivity, density/neutron tracks), geochemical measurement and interpretation (dry elemental WF, wet rock VF track), interpreted fluid type, saturation and porosity values (fluid volume, saturation, porosity track); Well-1, depth interval 3218-3242 m.

Two basic datasets were considered for the analysis of the laboratory measurement results (Tables 2 and 3).

Two plots illustrate relationships between bulk density from MIP and TOC (from Rock-Eval) (Figure 6a) and also organic matter from XRD/TOC analyses vs. total pore volume V_tot, determined from the nitrogen adsorption/desorption at $77 \mathrm{~K}$ experiment (Figure $6 \mathrm{~b}$ ). Data from Figure 6 are based on the more numerous dataset (Table 2), originating from the pressure decay permeability measurements, and comprising data from Well-1 and Well-3. The next two plots present the relationships between pressure decay permeability PD_Perm (in microdarcy) and total pore volume determined from the nitrogen adsorption/desorption at $77 \mathrm{~K}$ experiment (Figure 6c) and total pore area from the MIP (Figure 6d). In all plots data scattering is observed. The main reasons for the data scattering are different physical phenomena, being the basis of the measurement techniques, resulting in different resolution. Heterogeneity of shale formations is the next factor complicating the relationships $[39,40]$. Nevertheless, correlation of data is observed, which means that the recorded quantities related to shale formation are mutually dependent and may be used to characterize the rock. The outlier observed in the Figure 6a (marked in red) (Well-1, Sa Fm) is related to sample of the highest percent of pyrite, which resulted in the increase of bulk density in the presented level of TOC. One of the outliers in the Figure $6 \mathrm{c}$ (marked in red) belongs to Pr Fm and consists of the extreme value of Fe-chlorite, which resulted in grain density increase (Table 2). PD_Perm coordinate shows that chlorite provided different influence on pore space in comparison to illite/montmorillonite, of which clay minerals dominated in the considered formations. The second outlier (in orange) represents Sa Fm and is rich in quartz and organic matter. Increased volume of quartz resulted in increased permeability. Visible relations between parameters, measured in various experiments, allow expecting that similar trends will be extended to extremely detailed parameters obtained from microtomography. 
Table 2. Petrophysical parameters of the samples selected for the pressure decay permeability and other laboratory measurements.

\begin{tabular}{|c|c|c|c|c|c|c|c|c|c|c|c|c|}
\hline Sample & $\begin{array}{l}\text { Depth } \\
\text { (m) }\end{array}$ & Stratigraphy & $\begin{array}{c}\text { TOC } \\
\text { (Rock-Eval) } \\
\text { (wt \%) }\end{array}$ & $\begin{array}{c}\text { Bulk } \\
\text { Density } \\
\text { (MIP) (g/cc) }\end{array}$ & $\begin{array}{c}\text { Grain } \\
\text { Density } \\
(\mathrm{HeP})(\mathrm{g} / \mathrm{cc})\end{array}$ & $\begin{array}{l}\text { Porosity } \\
\text { (MIP) (\%) }\end{array}$ & $\begin{array}{c}\text { Total Pore } \\
\text { Area (MIP) } \\
\left(\mathrm{m}^{2} / \mathrm{g}\right)\end{array}$ & $\begin{array}{l}\text { V-tot } \\
\text { (cc/g) }\end{array}$ & $\begin{array}{c}\text { OM } \\
\text { (wt \%) }\end{array}$ & $\begin{array}{l}\text { Permeability } \\
\text { (Pulse D) } \\
*\left(1^{-3}\right)(\mathrm{mD})\end{array}$ & $\begin{array}{c}\text { Bulk } \\
\text { Density } \\
\text { (PD) (g/cc) }\end{array}$ & $\begin{array}{l}\text { Permeability } \\
(\text { Pressure D) } \\
{ }^{*}\left(\mathbf{1 0}^{-3}\right)(\mathrm{mD})\end{array}$ \\
\hline & & & \multicolumn{8}{|c|}{ Standard Laboratory Measurements } & \multicolumn{2}{|c|}{ Pressure Decay } \\
\hline Well-1(11) & 3216 & Sa Fm & 4.31 & 2.39 & 2.60 & 2.24 & 3.84 & 0.018 & 4.9 & 0.307 & 2.516 & 0.109 \\
\hline Well-1(13) & 3221.5 & Sa Fm & 3.88 & 2.33 & 2.60 & 1.01 & 1.89 & 0.024 & 4.5 & 582.8 & 2.488 & 0.197 \\
\hline Well-1(16) & 3228.5 & Sa Fm & 0.72 & 2.47 & 2.70 & 1.28 & 2.46 & 0.031 & 0.9 & & 2.648 & 0.069 \\
\hline Well-1(25) & 3233 & Sa Fm & 2.28 & 2.41 & 2.64 & 1.68 & 3.48 & 0.023 & 2.7 & & 2.609 & 0.070 \\
\hline Well-1(26) & 3234 & Sa Fm & 2.95 & 2.61 & 2.633 & 1.03 & 1.93 & 0.021 & 3.4 & 22.81 & 2.586 & 0.105 \\
\hline Well-3(1) & 2870 & $\mathrm{~Pa} \mathrm{Fm}$ & 0.28 & 2.42 & 2.81 & 2.48 & 5.93 & 0.031 & 0.3 & & 2.707 & 0.093 \\
\hline Well-3(2) & 2871 & $\mathrm{Ja} \mathrm{Mb}$ & 7.15 & 2.36 & 2.54 & 1.10 & 2.49 & 0.017 & 7.9 & & 2.440 & 0.111 \\
\hline Well-3(3) & 2872 & $\mathrm{Ja} \mathrm{Mb}$ & 2.44 & 2.42 & 2.66 & 2.01 & 4.63 & 0.023 & 2.8 & & 2.536 & 0.111 \\
\hline Well-3(4) & 2875 & $\mathrm{Ja} \mathrm{Mb}$ & 4.07 & 2.36 & 2.61 & 1.35 & 2.24 & 0.021 & 4.7 & 2783 & 2.444 & 0.099 \\
\hline Well-3(5) & 2878 & $\mathrm{Ja} \mathrm{Mb}$ & 0.63 & 2.46 & 2.70 & 2.62 & 6.52 & 0.034 & 0.8 & & 2.594 & 0.078 \\
\hline Well-3(6) & 2882 & $\mathrm{Ja} \mathrm{Mb}$ & 1.12 & 2.47 & 2.70 & 1.48 & 2.90 & 0.03 & 1.3 & & 2.590 & 0.079 \\
\hline Well-3(7) & 2885 & Pr Fm & & 2.34 & & 0.98 & 1.26 & & 0.4 & 0.309 & 2.674 & 0.096 \\
\hline Well-3(12) & 2910 & Sa Fm & 0.99 & 2.44 & 2.68 & 2.27 & 3.37 & 0.034 & 1.2 & & 2.610 & 0.076 \\
\hline Well-3(16) & 2880 & $\mathrm{Ja} \mathrm{Mb}$ & 1.45 & 2.45 & 2.70 & 2.47 & 5.99 & 0.028 & 1.7 & & 2.583 & 0.109 \\
\hline Well-3(17) & 2887 & Pr Fm & 0.25 & 2.59 & 2.76 & 1.56 & 3.81 & 0.035 & 0.3 & & 2.667 & 0.147 \\
\hline Well-3(18) & 2908 & Sa Fm & 0.85 & 2.53 & 2.72 & 1.89 & 3.91 & 0.035 & 1.0 & & 2.622 & 0.083 \\
\hline
\end{tabular}

Table 3. Petrophysical parameters of the samples selected for the micro-CT measurements and other laboratory experiments. Symbols: CN avr (coordination number)—average number of branches (pore channels) coming out from one node (pore), unitless; Sw irr-irreducible water saturation from NMR, \%.

\begin{tabular}{|c|c|c|c|c|c|c|c|c|c|c|c|c|}
\hline Sample & $\begin{array}{l}\text { Depth } \\
\text { (m) }\end{array}$ & Stratigraphy & $\begin{array}{c}\text { TOC (Rock-Eval) } \\
\text { (wt \%) }\end{array}$ & $\begin{array}{l}\text { Bulk Density } \\
\text { (MIP) }(\mathrm{g} / \mathrm{cc})\end{array}$ & $\begin{array}{l}\text { Bulk Density } \\
\text { (PPD) }(\mathrm{g} / \mathrm{cc})\end{array}$ & $\begin{array}{c}\text { Porosity } \\
\text { (MIP) (\%) }\end{array}$ & $\begin{array}{l}\text { Total Pore Area } \\
\text { (MIP) }\left(\mathrm{m}^{2} / \mathrm{g}\right)\end{array}$ & $\begin{array}{c}\text { Sw Irr } \\
\text { (NMR) (\%) }\end{array}$ & $\begin{array}{c}\text { Permeability } \\
(\mathrm{PPD})^{*}\left(10^{-3}\right)(\mathrm{mD})\end{array}$ & CN Avr & $\begin{array}{l}\text { Avr Junction } \\
\text { Sample }\end{array}$ & $\begin{array}{c}\text { Feret } \\
\text { Coefficient }\end{array}$ \\
\hline & & & \multicolumn{7}{|c|}{ Standard Laboratory Measurements } & \multicolumn{3}{|c|}{ Micro-CT Parameters } \\
\hline Well-1(26) & 3234.11 & Sa Fm & 2.95 & 2.61 & 2.59 & 1.03 & 1.93 & 68.10 & 0.105 & 3.028 & 2.451 & 0.508 \\
\hline Well-2(1) & 2896.75 & $\mathrm{Ja} \mathrm{Mb}$ & 7.4 & 2.39 & 2.50 & 2.39 & 5.12 & 80.75 & 0.055 & 3.082 & 3.973 & 0.523 \\
\hline Well-2(4) & 2903.90 & $\mathrm{Ja} \mathrm{Mb}$ & 1.79 & 2.53 & 2.59 & 1.47 & 2.58 & 88.21 & 0.099 & 3.036 & 2.936 & 0.541 \\
\hline Well-2(7) & 2923.98 & $\mathrm{Sa} \mathrm{Fm}$ & 3.5 & 2.42 & 2.46 & 1.74 & 3.13 & 83.51 & 0.271 & 3.040 & 3.348 & 0.463 \\
\hline
\end{tabular}



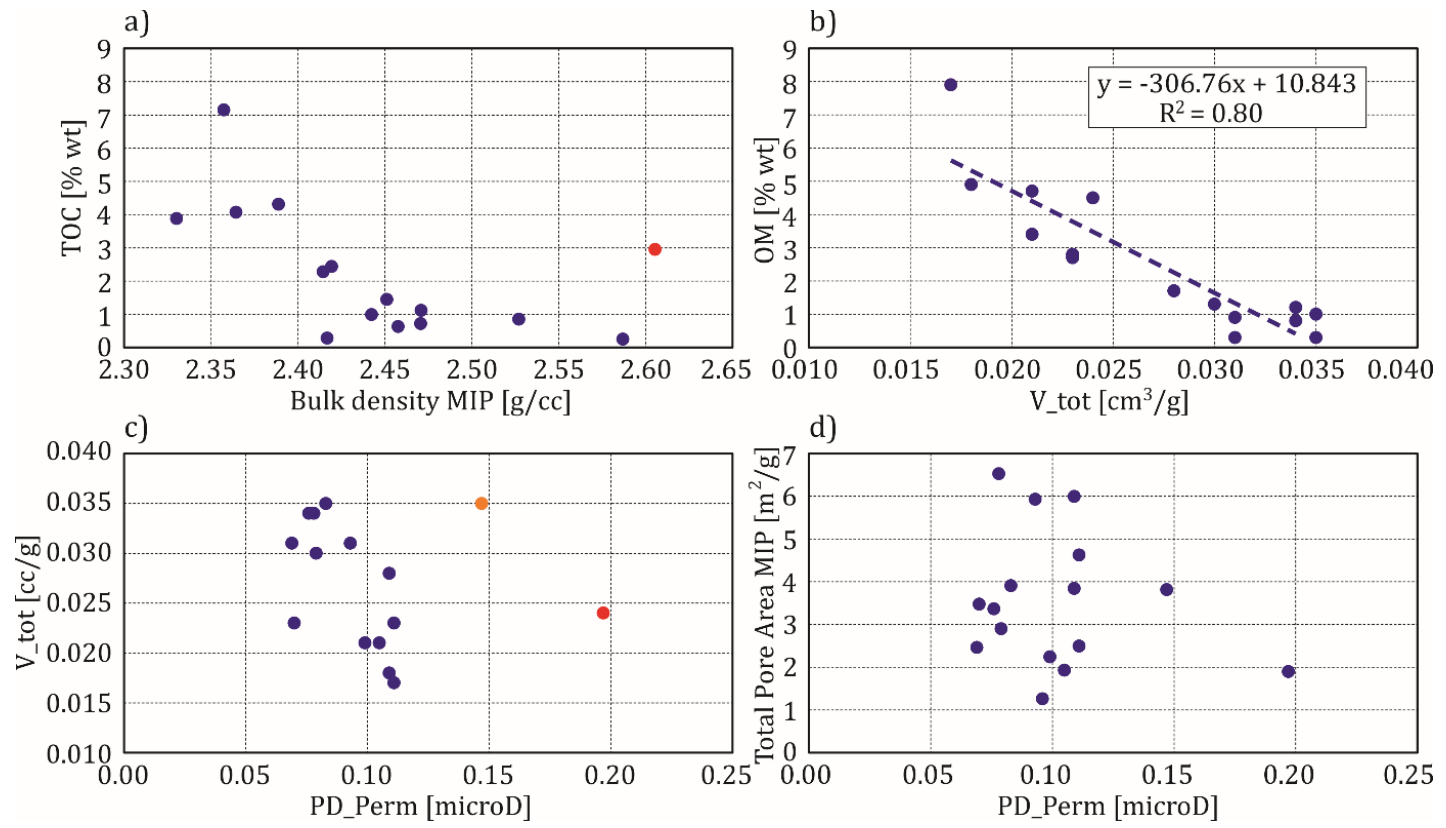

Figure 6. Relationships between parameters determined from standard laboratory experiments on samples from Well-1 and Well-2; (a) TOC (Rock-Eval) vs. bulk density from MIP; (b) organic matter OM (XRD/TOC analyses) vs. total pore volume V_tot (nitrogen adsorption/desorption at $77 \mathrm{~K}$ ); (c) total pore volume (nitrogen adsorption/desorption $\mathrm{N}$ at $77 \mathrm{~K}$ ) vs. pressure decay permeability PD_Perm; (d) total pore area (MIP) vs. pressure decay permeability PD_Perm; red and orange dots represent outliers described in the text.

The plots in Figure 7 illustrate MIP characteristics for the selected samples. Quantities, i.e., cumulative pore volume and incremental pore volume, are presented in percent, in relation to the maximal value of the corresponding parameter. There is observed broad pore-throat distribution, with the peaks at about $400 \mathrm{~nm}$, which are in accordance with the comparably low permeability (Table 2). Low cumulative pore volume is consistent with the determined porosity (Table 2). Modal shape of the incremental pore volume plots in Figure 7 reflected the pore space construction, different in both samples. One spike, located in section of small pore diameter in Figure $7 b$, means that nanopores influenced the porosity in this case. Several spikes in Figure 7a mean that porosity is built by pores from broad range of size, up to almost $3 \mu \mathrm{m}$.

a)

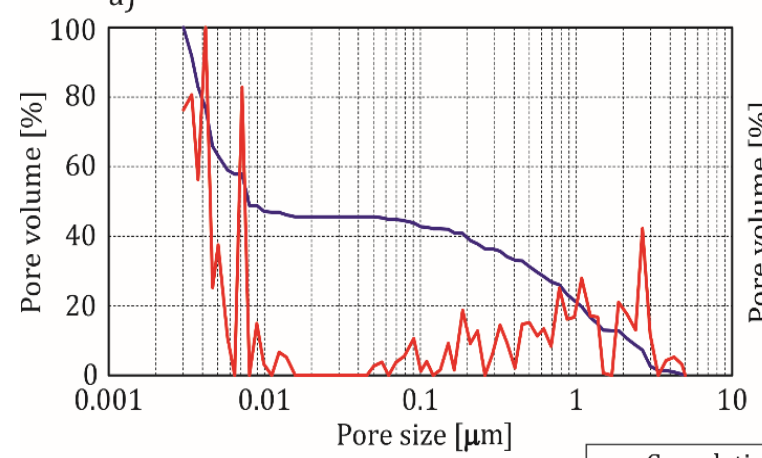

b)

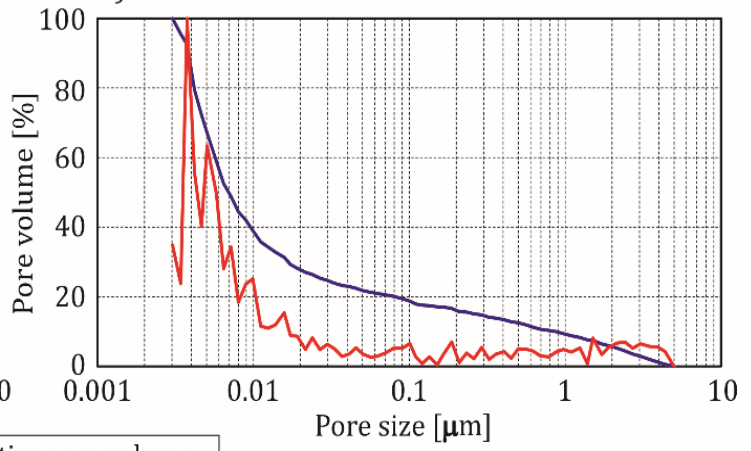

- Cumulative pore volume
- Incremental pore volume

Figure 7. Cumulative and incremental pore volume (MIP); (a) Well-1(26) sample; (b) Well-2(7) sample. 
Different courses of the cumulative pore volume curves (blue lines in Figure 7a,b) mean different activity of pores of related radii in the samples. Both samples, Well-1(26) and Well-2(7), represented Sa Fm, which confirms its heterogeneity regarding fluid flow ability.

Graphs in Figure 8 show how adsorption/desorption extended the porosity range, explored in laboratory methods. Samples presented in the Figure 8 are the same as those presented in Figure 7. In Figure $8 \mathrm{a}, \mathrm{c}$, a nitrogen volume at standard temperature and pressure (STP) is presented as a function of the relative pressure. The volume increment per increment of pore diameter, as a function of pore diameter, is presented in Figure 8b,d. It can be observed (Figure 8a,c) that a significant amount of gas, adsorbed at a low relative pressure, is indicative of microporosity. At the relative pressure of about 0.85 , the volume of gas adsorbed increased significantly as a result of the monolayer adsorption shifting to multilayer adsorption. Capillary condensation is observed at a relative pressure above 0.85. Due to the capillary condensation, the adsorption and desorption branches of the isotherm do not coincide. Thus, a hysteresis loop is formed with its shape, dependent on the pore structure. The complex shape of the hysteresis loop was probably due to the combination of several pore types. The height of shift isotherms depends on porosity. As an example, a higher porosity sample (Well-2(7), Table 3) is characterized by the bigger shift. Differences in porosity values and activity of pores of various diameters are also visible in MIP plots (blue lines). Large anomalies in Figure 8b,d indicate that large groups of small pores that were included in the gas movement network. It is important to observe, that only the density functional theory model (DFT) provides additional information about the microporosity. Higher maximum of the DFT curve in the Figure 8d plot means higher porosity of the Well-2(7) sample.

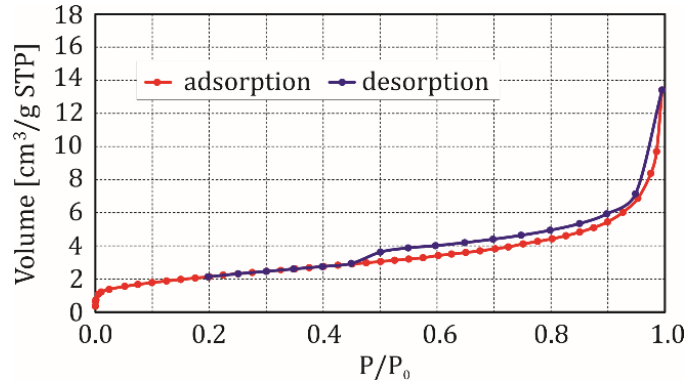

(a)

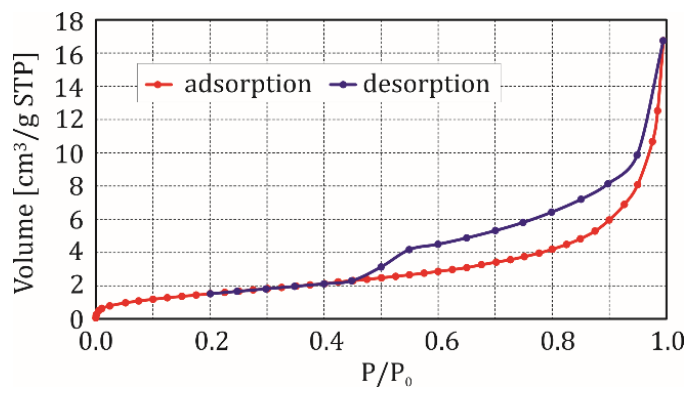

(c)

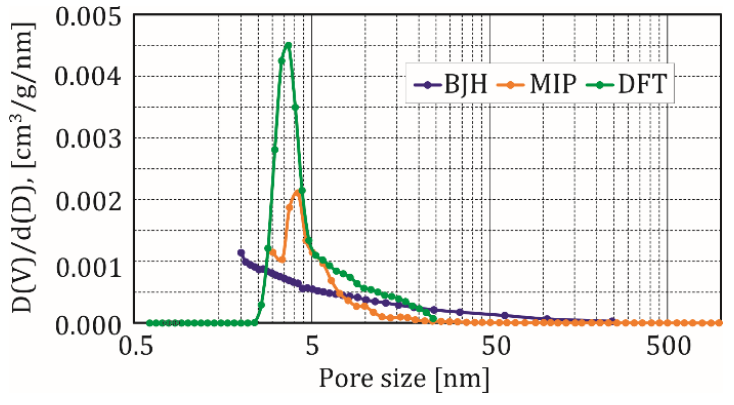

(b)

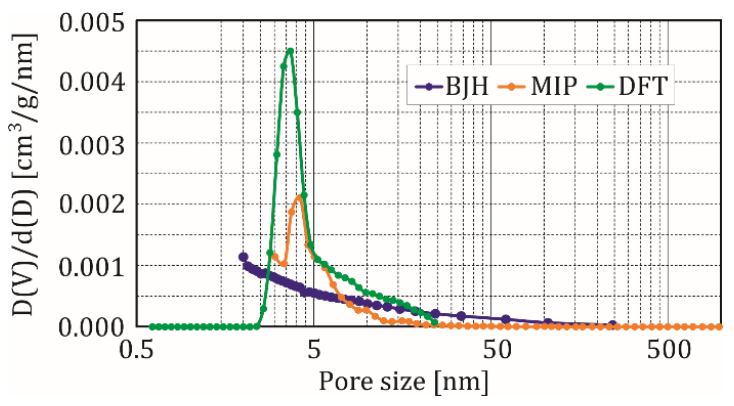

(d)

Figure 8. (a) Isotherm of adsorption/desorption of nitrogen, $77 \mathrm{~K}$, Well-1(26); (b) Pore size distribution according to BJH and DFT models and MIP, Well-1(26); (c) Isotherm of adsorption/desorption of nitrogen, $77 \mathrm{~K}$, Well-2(7); (d) Pore size distribution according to BJH and DFT models and MIP, Well-2(7).

The next series of plots are related to data obtained from the microtomography measurements for four samples. One of them, Well-1(26), is a junction between two sets (Tables 2 and 3). Results 
of the object (pores, microfractures) size classifications for the Well-1(26) and Well-2(7) samples are presented in the Table 4. Colored illustrations of the object (pores, microfractures) size classification are included in the Figure 9a,b. The Well-1(26) sample is characterized by the higher number of pores and microfractures in comparison to the Well-2(7) sample (as evidenced by the numbers in the SUM column). The most numerous volume class is class 100-999 voxels (orange, $\%$ column) for both samples, meaning that pores gathered within the volume range of $21.6-215 \mu \mathrm{m}^{3}$.

Table 4. Object size classification. Symbols: \#-number of objects in volume class; \%-percentage of volume class in the pore space.

\begin{tabular}{cccccccccc}
\hline $\begin{array}{c}\text { CT } \\
\text { Analysis }\end{array}$ & $\begin{array}{c}\text { Volume } \\
\text { Class } \\
\text { (voxels) }\end{array}$ & $\mathbf{1 - 9 9}$ & $\mathbf{1 0 0 - 9 9 9}$ & $\mathbf{1 0 0 0 - 9 9 9 9}$ & $\mathbf{1 0 , 0 0 0 - 9 9 , 9 9 9}$ & $\mathbf{1 0 0 , 0 0 0 - 9 9 9 , 9 9 9}$ & $\mathbf{7 1 , 0 0 0 , 0 0 0}$ & SUM \\
\hline Well-1(26) & $\#$ & 15,314 & 21,563 & 8020 & 1025 & 16 & 0 & 45,938 \\
\cline { 2 - 10 } & $\%$ & 33.33 & 46.94 & 17.46 & 2.23 & 0.04 & 0 & 100 \\
\hline Well-2(7) & $\#$ & 2211 & 3743 & 1440 & 73 & 4 & 0.05 & 0.01 & 100 \\
\cline { 2 - 10 } & $\%$ & 29.59 & 50.09 & 19.28 & 0.98 & & & 1 & 0 \\
\hline
\end{tabular}

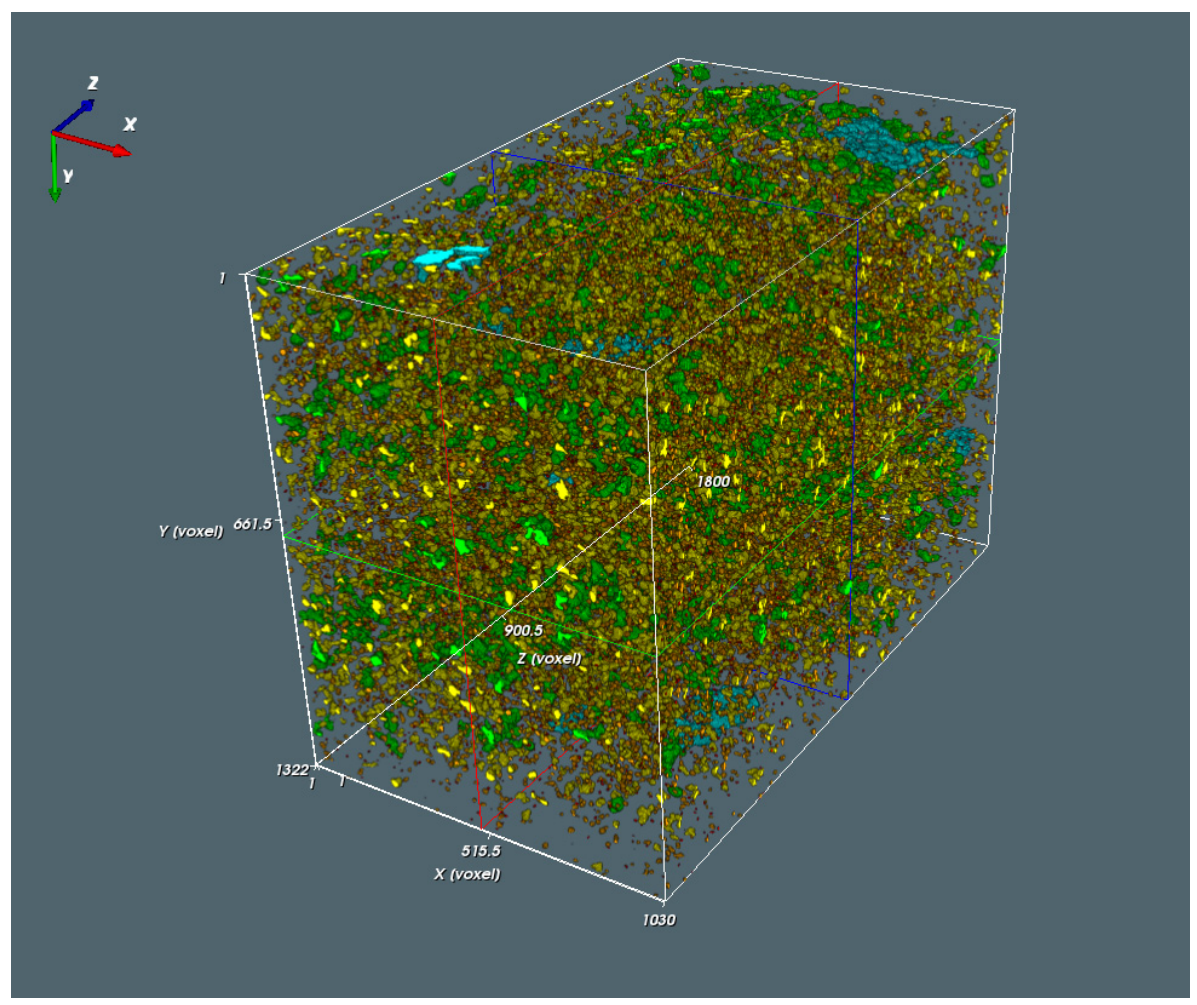

(a)

Figure 9. Cont. 


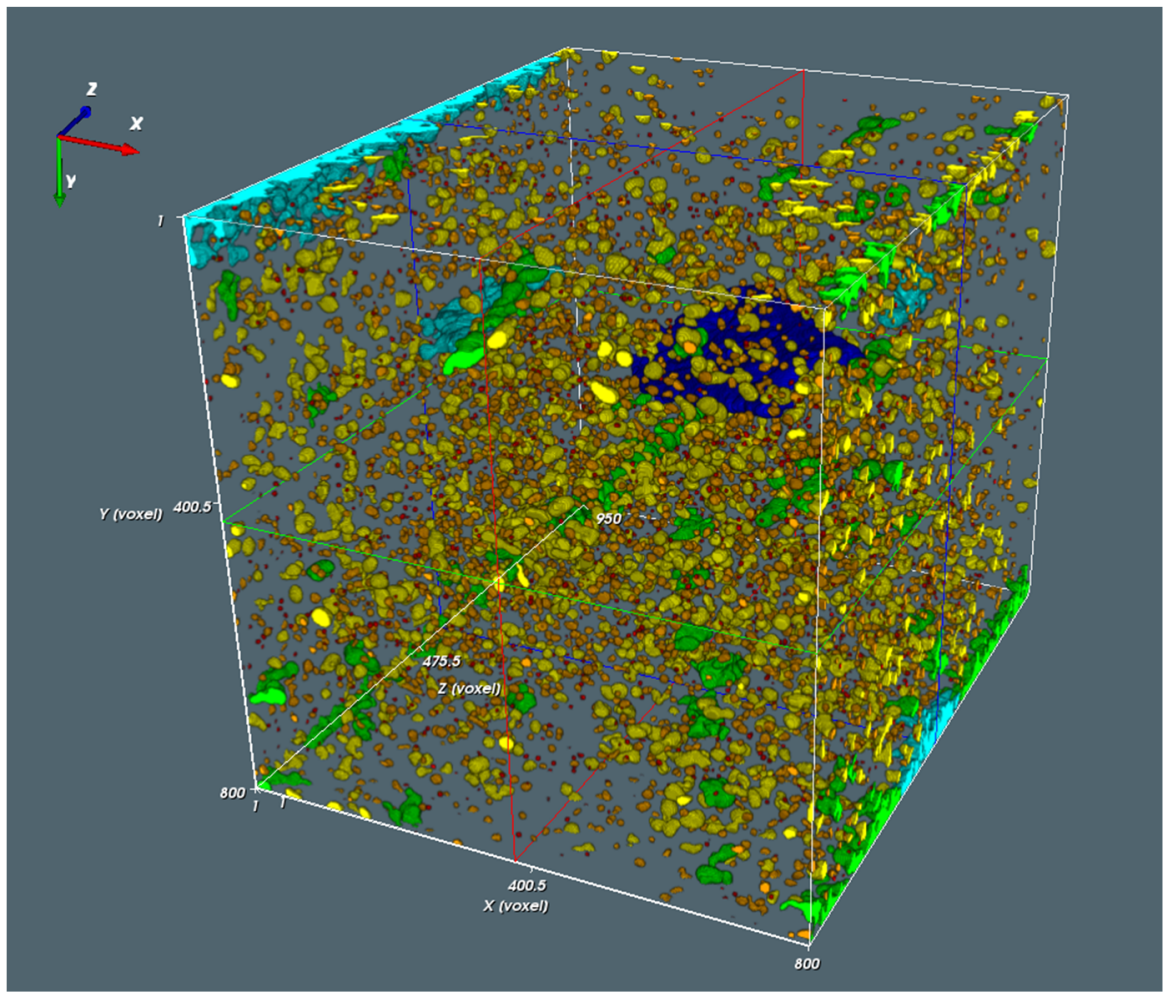

(b)

Figure 9. (a) Object size classification for the sample Well-1(26). Colors: red: 1-99 voxels, orange: 100-999, yellow: 1000-9999, green: 10,000-9,9999, light blue: 100,000-999,999, dark blue: above 100,0000 voxels. (b) Object size classification for the sample Well-2(7). Colors as in Figure 9a.

Relationships between parameters obtained from microtomography [41] and other laboratory methods are presented in Figure 10. At the beginning, analysis started with the mutual relation between parameters originating only from the microtomography (Figure 10a): average coordination number (calculated on the basis of the number of branches coming out from the one node) is on the horizontal axis, while average number of the junctions in the sample is on the vertical axis. The goal was to show that the correlation between parameters is visible and only one outlier is not from the Well-1, from which there was only one sample, but from the Well-2(1), from which there were three samples (Table 3). Plots in Figure 10a,b are similar in shape. In both cases, the outlier is the same (sample of CN Aver = 3.0820) and represents the group of three samples from the Well-2, belonging to the Silurian Ja Mb. The outlier in Figure 10c belongs also to the group of samples from Well-2. It is the Well-2(4) sample. It is observed that this was the highest value of the irreducible water, calculated from NMR experiment, in comparison to the others for this sample (Table 3). Highest Sw irr, together with the lowest permeability, resulted from the highest clay and organic matter content and lowest quartz content. This was detected on the basis of XRD/TOC analyses. Feret Coefficient is the next introduced parameter from the 3D analysis of the pore space and represents ratio of the maximum horizontal diameter to maximum vertical diameter of the pore (here, average value for the sample for all detected pores). High Feret Coefficient means meaningful difference between pore radii, measured in two perpendicular directions, which is related with the lowest elongation (ratio of the shortest chord to the longest chord) in the object. Comparing plots in Figure 10c,d, where Feret Coefficient in on the vertical axis, the same outlier can be observed-Well-2(4) sample. 


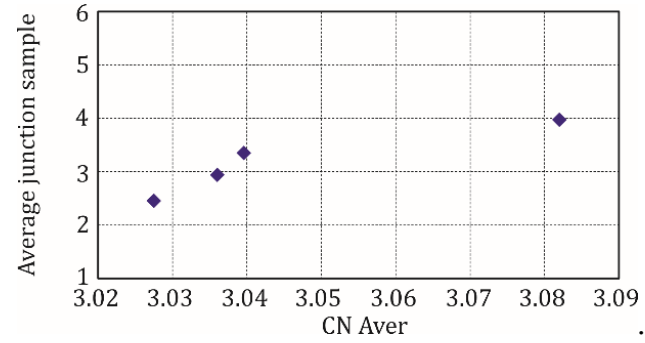

(a)

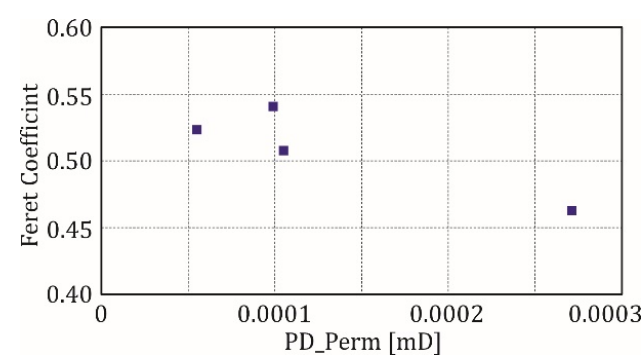

(c)

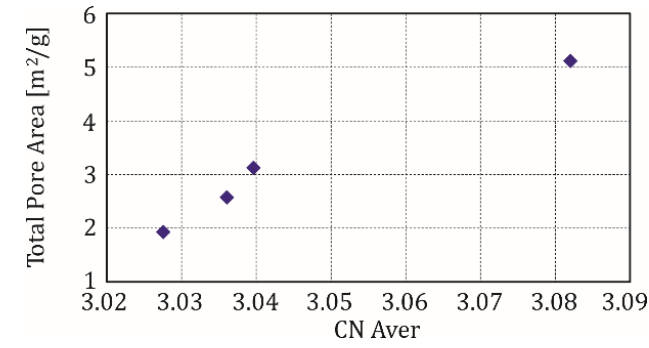

(b)

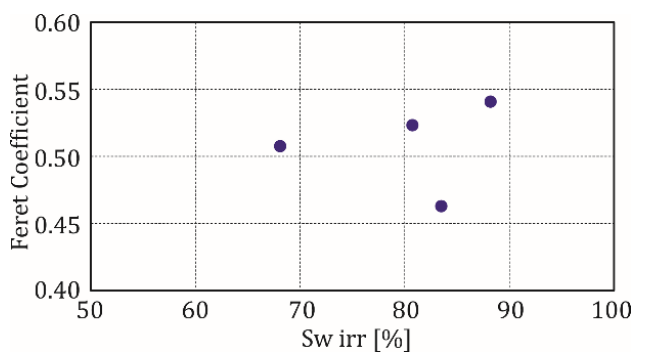

(d)

Figure 10. (a) Relationship between the average junction in the sample and average coordination number (CN Aver); (b) Relationship between TPA total pore area (MIP) and average coordination number (CN Aver); (c) Relationship between Feret Coefficient and pressure decay permeability (PD_Perm); (d) Relationship between Feret Coefficient and irreducible water saturation (Sw irr).

Mineral composition of the samples from Well-1(26) and Well-2(4 and 7) (Figure 11) could be compared on the basis of the XRD/TOC results. They differed regarding organic matter OM and the sum of clay minerals. High value of OM corresponds to low bulk density from MIP and PD_Perm, and high TOC (Rock-Eval). Samples Well-2(7) and (4) also differ among themselves as regards TOC and permeability PD_Perm. Sample Well-2(7) is characterized by the highest permeability. Main mineral components in all samples comprised quartz, orthoclase and plagioclases, calcite and dolomite, iron (pyrite/marcasite and hematite) and titanium (anatase) containing minerals, clay minerals such as an illite/montmorillonite group and chlorite. Diverse content of minerals, especially quartz (the highest value for which was found in the Well-2(7) sample) and organic matter, among others, caused the outlier position of the samples. The highest quartz amount found in the Well-2(7) sample may explain the highest permeability PD_Perm (Figure 10c), which continued the trend line, visible in the plot (decreasing of the Feret Coefficient with increased permeability). The outlier in Figure 10d, with high value of $S w$ irr, is related to relatively low sum of clay minerals and relatively high value of organic matter and permeability. In the presented results, there is an observed correlation with Feret Coefficient, not with Feret diameter. This means that diameters measured in different directions better describe the pore shape than diameter measured in one direction does, which means that pores have various shapes. High Sw irr, together with high PD_Perm, can be explained by water covering the surface of quartz grains (high quartz content) and identification of hydrogen in organic matter, not only in water by NMR experiment. Here, in the discussion, only pressure decay permeability was considered, but several pulse decay permeability results, especially for the Well-1(26) sample (Table 2), revealed that not only matrix micro/nanopores should be accounted for to illustrate the complex structure of shales. High values of the pulse and pressure decay permeability showed the presence of microfractures (partially originating naturally, partially being artifacts), increasing the porosity and permeability. Comparison of pressure and pulse decay permeability presented the range of permeability variability, from minimal value (pressure decay) to maximal value (pulse decay). 


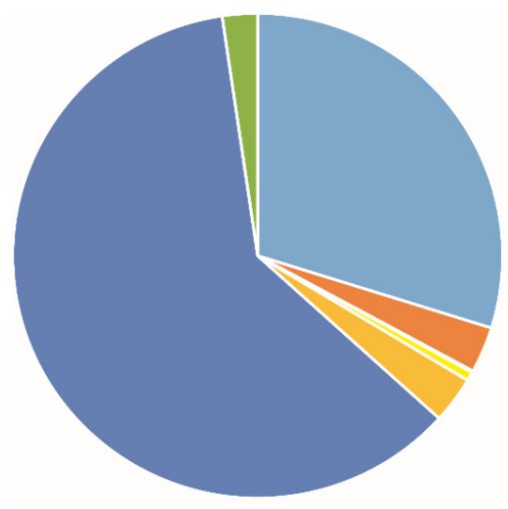

$1 \square 2 \square 3 \square 4 \square 5 \square 6 \square 7$

(a)

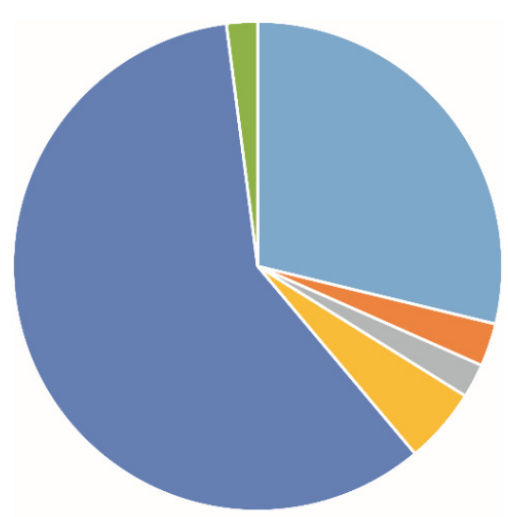

$\square 1 \square 2 \square 3 \square 4 \square 5 \square 6$

(b)

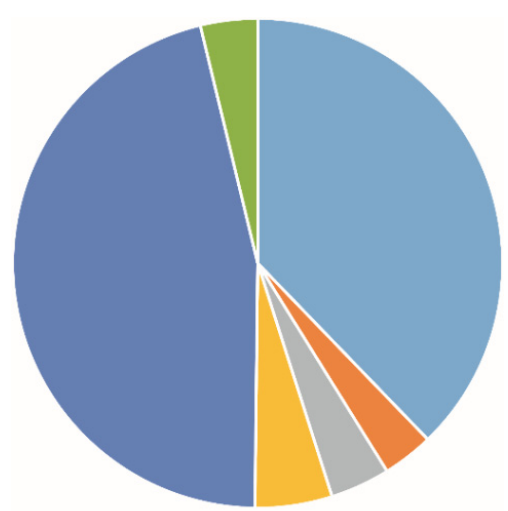

$\square 1 \square 2 \square 3 \square 4 \square 5 \square 6$

(c)

Figure 11. (a) Well-1(26) minerals and organic matter content (wt \%), 1-quartz, 2-orthoclase + plagioclase, 3-calcite + dolomite, 4-gypsum, 5-Fe/Ti-minerals, 6-clay minerals, 7-organic matter; (b) Well-2(4) minerals and organic matter content (wt \%), 1-quartz, 2-orthoclase + plagioclase, 3-calcite + dolomite, 4-Fe/Ti-minerals, 5-clay minerals, 6-organic matter; (c) Well-2(7) minerals and organic matter content (wt \%), 1-quartz, 2-orthoclase + plagioclase, 3-calcite + dolomite, 4-Fe/Ti-minerals, 5-clay minerals, 6-organic matter. 
Comprehensive analysis of the groups of plots in the Figures 6 and 10 show that correlation between parameters is not only observed in the groups of the results obtained from the same scale measurements.

\section{Conclusions}

Well logging and laboratory methods, together with the comprehensive workflow, were established, utilizing a combined analysis of petrophysical results to enable the rock characterization. In rock typing SGR, XRMI and GEM logs turned out to be the most effective in quick selection of formations of the highest hydrocarbon reservoir potential in the geological profile. All laboratory experiments provided important data. Some of the methods resulted in data redundancy, so, having the limited budget for laboratory experiments, some of the methods can be rejected. In the presented shale characterization MIP and adsorption/desorption of nitrogen at $77 \mathrm{~K}$ showed themselves indispensable, providing information on effective porosity (total pore volume), bulk density, total pore area and pore distribution. Combined MIP and adsorption/desorption of nitrogen at $77 \mathrm{~K}$ covered a large pore size range, from the fracture of millimeter to nanometer scale. This combination of laboratory methods provides a novel approach to porosity/permeability calculation; including the smallest pores changed the image of the rock. Combining the outcomes of MIP and nitrogen adsorption/desorption at $77 \mathrm{~K}$ brought qualitative data, for better understanding of the ability of media flow in shale formation. This is a great challenge, because the estimation of flow behavior in reservoirs often suffers from uncertainties associated with pore types and pore distributions. Pressure decay permeability was the important source of true matrix permeability. Microtomography analysis allowed a representative 3D assessment of total porosity, pore connectivity and pore shape. Correlations between measured petrophysical properties and parameters from the microtomography established the platform to combine the information from the diverse scale measurements. Trends observed in the relationships between parameters, determined from the outcomes from laboratory measurements and well logging, are promising results for the newest approach in well logging and standard laboratory experiments for digital rock model construction.

The main, detailed conclusions are:

- Microresistivity curves form the modern tools, such as FMI and XRMI, together with a geochemical $\log$ (GEM or LithoScanner), are a source of detailed lithology information, reflecting changes of thickness of claystone and mudstone laminas in gas shales.

- Spectral gamma ray log SGR is a key log for the quick identification of shale formations sections rich in organic matter.

- Correlation of the organic matter OM vs. total pore volume $V_{-}$tot (nitrogen adsorption/desorption at $77 \mathrm{~K}$ ) was observed with the correlation coefficient $R^{2}=0.8$, which demonstrated that the recorded parameters in the shale formation are mutually dependent and may be used to characterize the rock.

- MIP quantities illustrated the nanopores' influence (up to $3 \mu \mathrm{m}$ ) on the porosity of the shale formations and broad pore-throat distribution.

- Adsorption/desorption of nitrogen at $77 \mathrm{~K}$ gave the information that a significant amount of gas, adsorbed at a low relative pressure, is indicative of microporosity. Moreover, only the density functional theory model (DFT) delivered the additional information about the microporosity in analyzed shale formations.

- Computed X-ray tomography showed that the samples differed in the number of pores and microfractures (by almost 6-fold), but almost $50 \%$ of the pores were concentrated in the volume range of 100-999 voxels. Feret coefficient correlated with the pressure decay permeability for the analyzed samples and can be associated with the quartz content in the sample.

- Diverse content of minerals (from the XRD analysis) caused the outlier position of the samples for the different correlations of laboratory measurement results.

Author Contributions: P.I.K.-M.: conception, data analysis, results analysis, software, paper preparation; J.A.J.: conception, data analysis, results analysis, resources, paper preparation. All authors have read and agreed to the published version of the manuscript. 
Acknowledgments: This study was financed by The National Centre for Research and Development, Warsaw, Poland in the program Blue Gas, project: "Methodology to determine sweet spots based on geochemical, petrophysical and geomechanical properties in connection with correlation of laboratory test with well logs and generation model 3D" (MWSSSG) Polskie Technologie dla Gazu Łupkowego. Data for the study were provided by Polish Oil and Gas Company, Warsaw, Poland. Authors are grateful to the staff members of the AGH UST Faculty of Geology Geophysics and Environmental Protection-Edyta Puskarczyk for the NMR results, Roman Semyrka for the MIP measurements and Leszek Czepirski research group from the AGH UST Faculty of Energy and Fuels for the adsorption/desorption of nitrogen at $77 \mathrm{~K}$ measurements. poROSE software was financed by the National Centre for Research and Development in Poland, program LIDER VI, project no. LIDER/319/L-6/14/NCBR/2015: Innovative method of unconventional oil and gas reservoirs interpretation using computed X-ray tomography. Authors are also grateful to the poROSE software co-authors: Magdalena Habrat, Edyta Puskarczyk, Paweł Madejski, Mariusz Jędrychowski. The results were also partially supported by Dean of Faculty of Geology. Geophysics and Environmental Protection (the research subsidy no 16.16.140.315), AGH University of Science and Technology. Authors are very grateful to the reviewers for the chance to improve the manuscript.

Conflicts of Interest: The authors declare no conflict of interest.

\section{Abbreviation}

GR
SGR
URAN, U
THOR
POTA
LLD
LLS
RHOB
PE
RHOMA
DT
NPHI
Mg, Al, Si, K, Ca
Illite, Fe-Chlorite, Plagioclase, Quartz,
Dolomite, Calcite and Kerogen
Free water, Gas, Clay water and Kerogen
SWT
SWE
Por tot
Por eff
XRMI
TOC

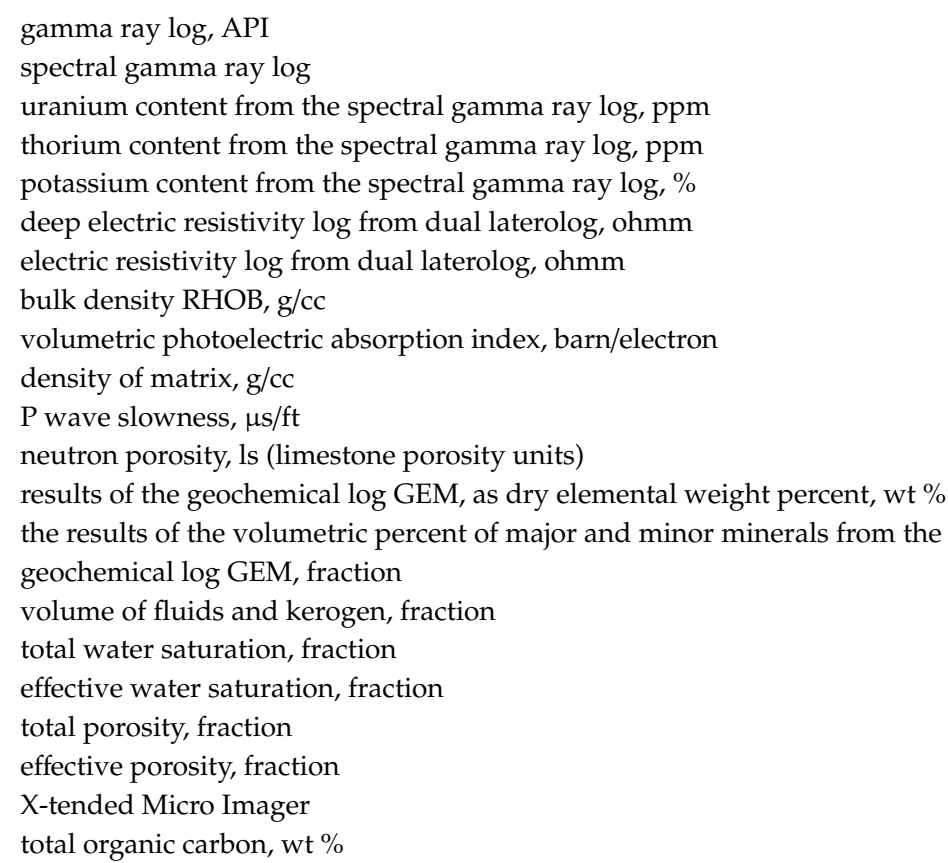

\section{References}

1. Kiersnowski, H. Geological Environment of Gas-Bearing Shales. In Shale Gas as Seen by Polish Geological Survey; Nawrocki, J., Ed.; Polish Geological Institute-National Research Institute: Warsaw, Poland, 2013; pp. 26-31.

2. Poprawa, P. Shale gas potential of the Lower Paleozoic complex in the Baltic and Lublin-Podlasie basins (Poland). Geol. Rev. 2010, 58, 226-249.

3. Jarzyna, J.; Wawrzyniak-Guz, K. Adaptation to the Polish Conditions of the Methodologies of the Sweet Spots Determination on the Basis of Correlation of Well Logging with Drilled Core Samples: Methodology to Determine Sweet Spots Based on Geochemical, Petrophysical and Geomechanical Properties in Connection with Correlation of Laboratory Test with Well Logs and Generation Model 3D; GOLDRUK Wojciech Golachowski Printing House: Nowy Sacz, Poland, 2017; 500p.

4. Golonka, J.; Pietsch, K.; Barmuta, J.; Bębenek, S.; Botor, D.; Porębski, S.; Papiernik, B.; Barmuta, M.; Michna, M. Paleozoic evolution of the Eastern European Platform in Poland and shale gas potential. In Proceedings of the ACE2017 Annual Convention \& Exibition 2017, 100 AAPG Anniversary, Houston, TX, USA, 2-5 April 2017.

5. Cyz, M.; Malinowski, M. Seismic azimuthal anisotropy study of the Lower Paleozoic shale play in northern Poland. Interpretation 2018, 6, SH1-SH12. [CrossRef] 
6. Cyz, M.; Mulińska, M.; Pachytel, R.; Malinowski, M. Brittleness prediction for the Lower Paleozoic shales in northern Poland. Interpretation 2018, 6, SH13-SH23. [CrossRef]

7. Więcław, D.; Kotarba, M.J.; Kosakowski, P.; Kowalski, A.; Grotek, I. Habitat and hydrocarbon potential of the lower Paleozoic source rocks in the Polish part of the Baltic region. Geol. Q. 2010, 54, 159-182.

8. Porębski, S.J.; Prugar, W.; Zacharski, J. Silurian shales of the East European Platform in Poland-Some exploration problems. Geol. Rev. 2013, 61, 630-638.

9. Podhalańska, T. Late Ordovician to Early Silurian transition and the graptolites from Ordovician/Silurian boundary near the SW rim of the East European Craton (northern Poland). Ser. Geol. Correl. 2003, 18, 165-172.

10. Tomczyk, H. Stratigraphic problems of the Ordovician and Silurian in Poland in the light of recent studies. Pr. Państwowego Inst. Geol. 1962, 35, 1-134.

11. Modliński, Z.; Szymański, B.; Teller, L. The Silurian lithostratigraphy of the Polish part of the Peri-Baltic Depression (N Poland). Geol. Rev. 2006, 54, 787-796.

12. Modliński, Z.; Szymański, B. The Ordovician lithostratigraphy of the Peribaltic Depression (NE Poland). Geol. Q. 1997, 41, 273-288.

13. Modliński, Z.; Szymański, B. Lithostratigraphy of the Ordovician in the Podlasie Depression and the basement of the Płock-Warsaw Trough (eastern Poland). Biul. Państwowego Inst. Geol. 2008, 430, 79-112.

14. Washburn, E.W. The Dynamics of Capillary Flow. Phys. Rev. 1921, 17, 273-283. [CrossRef]

15. Webb, P.A. An Introduction to the Physical Characterization of Materials by Mercury Intrusion Porosimetry with Emphasis on Reduction and Presentation of Experimental Data; Micrometrics Instruments Corp.: Norcross, Georgia, 2011.

16. Thommes, M.; Kaneko, K.; Neimark, A.V.; Olivier, J.P.; Rodriguez-Reinoso, F.; Rouquerol, J.; Sing, K.S.W. Physisorption of gases. with special reference to the evaluation of surface area and pore size distribution (IUPAC Technical Report). Pure Appl. Chem. 2015, 87, 9-10, 1052-1069. [CrossRef]

17. Rouquerol, F.; Rouquerol, J.; Sing, K.S.W.; Llewellyn, P.; Maurin, G. Adsorption by Powders and Porous Solids: Principles, Methodology and Applications; Academic Press: Cambridge, MA, USA, 2014.

18. Gor, G.Y.; Thommes, M.; Cychosz, K.A.; Neimark, A.V. Quenched solid density functional theory method for characterization of mesoporous carbons by nitrogen adsorption. Carbon 2012, 50, 1583-1590. [CrossRef]

19. Thommes, M. Physical Adsorption Characterization of Nanoporous Materials. Chem. Ing. Tech. 2010, 82, 1059-1073. [CrossRef]

20. Donohue, M.D.; Aranovich, G.L. Classification of Gibbs adsorption isotherms. Adv. Colloid Interface Sci. 1998, 76-77, 137-152. [CrossRef]

21. Jarzyna, J.A.; Czepirski, L.; Krakowska, P.I.; Puskarczyk, E.; Szczurowski, J. Petrophysical Model of Polish Shale Gas Rocks on the Basis of Various Laboratory Experiments. In Proceedings of the 79th EAGE Conference and Exhibition, EarthDoc, Paris, France, 12-15 June 2017. [CrossRef]

22. Dudek, L. Pore size distribution in shale gas deposits based on adsorption isotherm analyses. Naft.-Gaz 2016, 8, 603-609. [CrossRef]

23. Coates, G.R.; Xiao, L.; Prammer, M.G. NMR logging Principles \& Applications; Halliburton Energy Service: Houston, TX, USA, 1999.

24. Puskarczyk, E. Assessment of Reservoir Properties of Rock through Nuclear Magnetic Resonance Phenomenon Application. Ph.D. Thesis, AGH University of Science and Technology, Krakow, Poland, 2011.

25. Terra Tek Schlumberger Reservoir Laboratory. TRA Glossary; Terra Tek Schlumberger Reservoir Laboratory: Houston, TX, USA, 2016.

26. Jarzyna, J.A.; Krakowska, P.I.; Puskarczyk, E.; Wawrzyniak-Guz, K.; Bielecki, J.; Tkocz, K.; Tarasiuk, J.; Wroński, S.; Dohnalik, M. X-ray computed microtomography-A useful tool for petrophysical properties determination. Comput. Geosci. 2016, 20, 1155-1167. [CrossRef]

27. Krakowska, P.I. Project Report: Innovative Method of Unconventional Oil and Gas Reservoirs Interpretation Using Computed X-ray Tomography; National Centre for Research and Development: Warsaw, Poland, 2019; unpublished.

28. Krakowska, P.; Puskarczyk, E.; Jędrychowski, M.; Habrat, M.; Madejski, P.; Dohnalik, M. Innovative characterization of tight sandstones from Paleozoic basins in Poland using X-ray computed tomography supported by nuclear magnetic resonance and mercury porosimetry. J. Pet. Sci. Eng. 2018, 166, 389-405. [CrossRef] 
29. Madejski, P.; Krakowska, P.; Habrat, M.; Puskarczyk, E.; Jędrychowski, M. Comprehensive Approach for Porous Materials Analysis Using a Dedicated Preprocessing Tool for Mass and Heat Transfer Modeling. J. Therm. Sci. 2018, 27, 479-486.

30. Topór, T.; Derkowski, A.; Kuila, U.; Fischer, T.B.; McCarty, D.K. Dual liquid porosimetry: A porosity measurement technique for oil-and gas-bearing shales. Fuel 2016, 183, 537-549. [CrossRef]

31. Kuila, U.; McCarty, D.K.; Derkowski, A.; Fischer, T.B.; Prasad, M. Total porosity measurement in gas shales by the water immersion porosimetry (WIP) method. Fuel 2014, 117, 1115-1129. [CrossRef]

32. Środoń, J.; Drits, V.A.; McCarty, D.K.; Hsieh, J.C.C.; Eberl, D.D. Quantitative XRD analysis of clay-rich rocks from random preparations. Clays Clay Miner. 2001, 49, 514-528. [CrossRef]

33. Omotoso, O.; McCarty, D.K.; Hillier, S.; Kleeberg, R. Some successful approaches to quantitative mineral analysis as revealed by the 3rd Reynolds Cup contest. Clays Clay Miner. 2006, 54, 748-760. [CrossRef]

34. Zorski, T.; Jarzyna, J.; Derkowski, A.; Środoń, J. Geofizyka otworowa w dobie poszukiwań gazu w łupkach-modele interpretacyjne i specyfika zastosowań w zagadnieniach rozpoznawania złóż gazu z łupków. Geol. Rev. 2013, 61, 478-488. (In Polish)

35. Kotarba, M.J.; Lewan, M.; Więcław, D. Shale gas and oil potential of Lower Palaeozoic strata in the Polish Baltic Basin by Hydrous Pyrolysis. Presented at the Fourth EAGE Shale Workshop. Shales: What do they have in common? In Proceedings of the 4th EAGE Shale Workshop, Porto, Portugal, 6-9 April 2014.

36. Curve Mnemonic Dictionary. Available online: www.slb.com (accessed on 25 January 2020).

37. Wireline \& Perforating, Formation Evaluation. Available online: www.halliburton.com (accessed on 25 January 2020).

38. PGNiG SA. Halliburton GEM Mineralogical \& Petrophysical Interpretation Summary; PGNiG SA: Warsaw, Poland, 2013.

39. Rahmani, O.; Khoshnoodkia, M.; Kadkhodaie, A.; Pour, A.B.; Tsegab, H. Geochemical Analysis for Determining Total Organic Carbon Content Based on LogR Technique in the South Pars Field. Minerals 2019, 9, 735. [CrossRef]

40. Liu, J.; Yao, Y.; Elsworth, D.; Liu, D.; Cai, Y.; Dong, L. Vertical Heterogeneity of the Shale Reservoir in the Lower Silurian Longmaxi Formation: Analogy between the Southeastern and Northeastern Sichuan Basin, SW China. Minerals 2017, 7, 151. [CrossRef]

41. PoROSE Help. 2018. Available online: www.porose.pl (accessed on 25 January 2020).

(C) 2020 by the authors. Licensee MDPI, Basel, Switzerland. This article is an open access article distributed under the terms and conditions of the Creative Commons Attribution (CC BY) license (http://creativecommons.org/licenses/by/4.0/). 